を向上させるのに影響を与えるかを日立多軌道断層装置 を用いて，断層撮影面の MTF を求め比較検討した， そ の結果多種軌道間に MTF の差が無く, 絞りが小さい場 合には画質の向上がみられた．また立分絞った時は，整 線板の有無は画質に影響を与えないととが判った。従っ て断層撮影装置に多軌道が存在する意義は，断層撮影面 について情報量に差は無く，障害除影の形状とその量と 汇意義が苟る之考えられる。

尚現在は多重絞りに改良した。

\section{8. 二次線除去グリッド使用法の再検討}

東邦大学医学部附属大森病院

大砂 和男・泉 重光・橋爪 俊幸

二次線除去グリッドを使用して撮影を行なった場合， グリッドと螢光体の間隔が大きくなると, 対照度が極端 低下し㟝断の妨げとなることがある．との原因として 二次線含有率の変化が考えられるので，我々はアクリル ファントーム主びに螢光量計を用いて，グリッドと增感 紙の間隔による二次線含有率の変化について検討した。 その結果，グリッドと増感紙が密着した時二次線含有率 が最も少なく，間隔が大きくなるにつれ含有率が增加す る。また間隔が小さい程管電圧を低くするととにより含 有率は減少し，逆に3cm以上になると管電生には殆えど 無関係に一定値を示した。また二次線舀は間隔の大小に

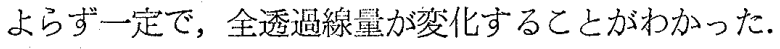

\section{質問}

表10二次線含有率が非常に多け様ですがいかがでし ょうか。大体 $5: 1$ で $80 \mathrm{kVp}$ 以下なら二次線含有率は10\% 以下が普通之思います。.

宇津見博基（山口）

\section{答}

二次線含有率測定法が，貴実験ではスリットビームに よるファントーム遠近法がすちいられているが，われわ れは抄録に示す上うに先ず透過全線量を求め，次愎光 量計受光面をカバーずるに要する最小面積の鉛板をむち いて二次線を求めて語算したすのであるため当然その值 に差がでてくるすの之考えられる。

\section{質問}

(1) 表1の結果について疑問を感じ追試をして見たと ころ下表の如くなった，貴実験における透過線螢光量が グリッドを離すととによっててのように減少するととを どのように解勫したらよいか。

(2) 荐察において透過線螢光量の增減について鉛筞か らの特性エックス線によると結論づけて岗るが，あう少 しくわしくご説明いただきたい.

\begin{tabular}{|c|c|c|c|c|}
\hline 電 圧 & $\begin{array}{l}\text { Grid 壃 } \\
\text { 感紙距 }\end{array}$ & $\begin{array}{l}\text { 透過線 } \\
\text { 螢光量 }\end{array}$ & $\begin{array}{l}\text { 營光 線 } \\
\text { 量 }\end{array}$ & $\begin{array}{l}\text { 吾次線 } \\
\text { 蟀 }\end{array}$ \\
\hline \multirow{2}{*}{$60 \mathrm{kVp}$} & $0 \mathrm{~cm}$ & 12.5 & 2.0 & $16 \%$ \\
\hline & $3 \mathrm{~cm}$ & 13.0 & 2.5 & $19.2 \%$ \\
\hline \multirow{2}{*}{$80 \mathrm{kVp}$} & $0 \mathrm{~cm}$ & 64.0 & 13.0 & $20.3 \%$ \\
\hline & $3 \mathrm{~cm}$ & 66.0 & 14.8 & $22.5 \%$ \\
\hline
\end{tabular}

仁科 静夫（茨城）

答

(1) 貴追試においては，われわれの寒験とまったく逆 の結果が得られたとのととであるが，実験方法とくに直 接線遮へい用鉛板の大きさや鉛板之螢光量計受光面の微 細な位置的関係によるものではないかと考えられる。

尚，貴追試においては密着と $3 \mathrm{~cm}$ の 2 点のみであるの で $1,2 \mathrm{~cm}$ についてす追試を打願いしたい。

(2) グリッドと増感紙を密着するととにより透過線螢 光量が増加し，尚かつ臨床写真に㧍いても同一条件で高 濃度となりコントラストあ增すととは，グリッド鉛䈹よ り発生する特性エックス線 L列1．3(15keV) 亿よるあの ではないかと考えられる。

\section{9. 高電圧撮影時におけるフィルター効果の検討（フ イルター変化によるX線像の低周波数解析）} 東北大学医学部附属病院 放射線部 鈴木 正吾·有馬 宏寧・石井 出一 小松田 泰・浅野 茂夫・岩沢 史雄

[目的]

従来不利とされている骨の高圧撮影を行ない，微細像 の検討のためミクロフォトメーターと超低周波数解析装 置を組合せ，微細陰影成分の量を測定しフイルターの画 貿におよぼす影響について検討した。

[方法]

実験(1)バーガーファントームを使用し，認知能測定， 笑験(2)大腿骨微細像解析実験，寒験(1)(2)に打して，70， $150 \mathrm{kVp}$ 亿おいては銅フィルター厚さ $0.5 \mathrm{~mm}$ と $1.5 \mathrm{~mm}$ の 2 種類を使用しそれぞれ撮影を行なった。

[結果]

実験(1)(2)において高圧になるにしたがい及フイルター を厚くする事により認知能が良く又陰影成分の娍少が認

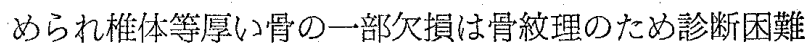
とされている点加らすればむしろ，それらの診断のため には実験(1)(2)の結果よりフイルターの選択による高圧撮 影が有利な場合があると考える。

質問

微細除影成分の定量化を考えられているにすかかわら ずなぜ Fig. 1 のような大まかなファントームを用いて実 